\title{
Temperature Dependency of Photosynthesis of Sphagnum spp. Distributed in the Warm-Temperate and the Cool-Temperate Mires of Japan
}

\begin{abstract}
Akira Haraguchi, Nanae Yamada
Faculty of Environmental Engineering, The University of Kitakyushu, Kitakyushu, Japan. Email: akhgc@kitakyu-u.ac.jp

Received August 22 ${ }^{\text {nd }}$ 2011; revised September 25 ${ }^{\text {th }}$, 2011; accepted October 25 2011.

ABSTRACT

We investigated the temperature dependency of photosynthetic rates for five Sphagnum species: Sphagnum palustre, $S$. fimbriatum in the Tadewara mire (south-western Japan in a warm-temperate zone) and S. papillosum, S. fuscum, $S$. fallax in the East Ochiishi mire (north-eastern Japan in a cool-temperate zone) measuring photosynthetic light response within a temperature range between 5 and $40^{\circ} \mathrm{C}$. The maximum photosynthetic rate was obtained at $T=35^{\circ} \mathrm{C}$ for $S$. palustre, S. fuscum and S. papillosum, and at $T=30^{\circ} \mathrm{C}$ for $S$. fimbriatum and S. fallax. Photosynthetic rates of all these species showed a maximum at $300-500 \mu \mathrm{mol} \cdot \mathrm{m}^{-2} \cdot \mathrm{s}^{-1}$ of PPFD and it decreased at higher PPFD $\left(>500 \mu \mathrm{mol} \cdot \mathrm{m}^{-2} \cdot \mathrm{s}^{-1}\right)$ under low temperature $\left(5^{\circ} \mathrm{C}-10^{\circ} \mathrm{C}\right)$. These results imply that Sphagnum species are not fully physiologically adapted to low temperature environments, although Sphagnum species distribute mostly in the circumpolar region.
\end{abstract}

Keywords: Carbon Dioxide Exchange, Photosynthesis, Sphagnum, Temperature Dependence

\section{Introduction}

Carbon accumulation by peat-forming plants is a great concern for the global carbon cycle [1,2]. Sphagnum plants are major components of vegetation in boreal mires and form thick peat layers containing huge amounts of organic carbon. Decomposition of peat causes the emission of carbon into the atmosphere, whereas deposition of peat promotes accumulation of carbon in the soil. In addition, the balance of peat formation and decomposition controls net carbon flow between the rhizosphere and the atmosphere.

The growth and primary productivity of Sphagnum spp. have been investigated under different conditions of water deficiency, nutrition, acidity, temperature, UV radiation and atmospheric pollution from pollutants such as ozone or bisulphate. Prior eco-physiological studies of Sphagnum plants clarified that most of the Sphagnum spp. grow well under acidic and poor nutritional conditions $[3,4]$. Sphagnum spp. are acidophilic species and the plants change the habitat acidity by exchanging soluble cations with protons at the cell walls of the plants. Only some few species such as $S$. squarrosum and $S$. fim- briatum can colonize under calcareous conditions [5]. Colonization of these pioneer Sphagnum spp. acidifies the habitat and then other species are able to colonize the acidic habitat. The growth of Sphagnum declined in growth media with high nutrient concentrations, especially those containing high levels of inorganic phosphorus [4].

Although the growth responses of Sphagnum plants to various environmental parameters have already been investigated, physiological responses of Sphagnum spp. such as photosynthetic activity have not been fully investigated. The water availability of habitats or the water contents of plants are among the limiting factors of the photosynthetic activity of Sphagnum [6-8]. Many Sphagnum spp. have optimal water contents for photosynthesis at $600 \%-800 \%$ of dry weight and the photosynthetic rate rapidly decreases when the water content becomes lower than the optimal. Desiccation tolerance of Sphagnum plants can be evaluated by the minimum water content in plants that maintain photosynthetic activity and the duration of dehydration from which the plants can recover physiological activity after rehydration $[9,10]$. 
Desiccation tolerance depends on the species and it determines the distribution of Sphagnum species along the gradients of microtopography within a mire community [3]. Hummock-forming species have a high tolerance for desiccation. Sphagnum spp. in section Acutifolia have high desiccation tolerance because the green cells face the adaxial surface and in addition the green cells are covered with hyaline cells which face the abaxial surface. Species growing on hollow or submerged species are poorly adapted to dry conditions, although the species can survive under dry conditions for a short period. Sphagnum spp. in section Cuspidata have low desiccation tolerance because of their leaf anatomical structure is the opposite of that found in species in section Acutifolia.

Recent studies on the relationship between Sphagnum growth and nutrition have been focused on atmospheric nitrogen deposition [11-16] and many studies showed that enhanced nitrogen deposition accelerates the photosynthetic rate of Sphagnum plants, whereas growth of plants was limited by the deposition of atmospheric nitrogen.

Effects of environmental pollutants on the photosynthesis of Sphagnum plants have also been of great concern. Bisulphite $\left(\mathrm{HSO}_{3}^{-}\right)$in the atmospheric deposition has an extremely inhibiting effect on Sphagnum photosynthesis [17-19], and $5.0 \mathrm{mM}$ of $\mathrm{HSO}_{3}^{-}$has a completely fatal effect on Sphagnum. Iron deposition accompanying bisulphite deposition from the atmosphere decreases the effect of bisulphite on Sphagnum, and thus plants growing in polluted areas have higher tolerance capability for atmospheric pollution [20].

Ozone also has an inhibiting effect on the photosynthesis of Sphagnum plants. Sphagnum elongation and photosynthetic rate declined after 6 - 9 weeks of $\mathrm{O}_{3}$ exposure at $70-80 \mathrm{ppb}$ [21]. Respiration rate of Sphagnum plants increased after exposure to $\mathrm{O}_{3}$, although the photosynthetic rate was not affected by $\mathrm{O}_{3}$ exposure $[21,22]$.

Increased UV-B radiation inhibited elongation and dark respiration, but the effect of UV-B radiation increase on net photosynthetic rate per unit dry weight of plants was not significant [23]. Reduction of solar UV-B increased height growth but decreased volumetric density in S. magellanicum; furthermore, UV-B reduction had little effect on biomass production [24,25].

In addition to the effects of environmental pollution and UV radiation, global environmental change's influence on the photosynthetic activity of Sphagnum plants is also of great concern because the growth and decomposition of senescent plant materials determine the accumulation rate of organic carbon in peat soil and the consequent global carbon balance. As for the photosynthetic capacity of individual Sphagnum plants, the re- sponse of growth and photosynthetic rate to the temperature regime has been investigated by various researchers. Investigation on the growth of $S$. fuscum, S. balticum, $S$. cuspidatum and $S$. magellanicum under different temperature conditions ranging from $\mathrm{T}=11.2^{\circ} \mathrm{C}$ to $21.4^{\circ} \mathrm{C}$, and all of these Sphagnum plants showed maximum growth at $\mathrm{T}=21.4^{\circ} \mathrm{C}$ [26]. Temperature dependence of Sphagnum photosynthetic rates by using experimental measurement data as well as a theoretical model showed that maximum net photosynthetic rate along a particular temperature regime differed according to light intensity [27]. The optimal temperature in low light intensity conditions $\left(\right.$ PPFD $=20 \mu \mathrm{mol} \cdot \mathrm{m}^{-2} \cdot \mathrm{s}^{-1}$ ) was $\mathrm{T}=0^{\circ} \mathrm{C}$ to $5^{\circ} \mathrm{C}$, whereas in high light intensity conditions (PPFD $=500 \mu \mathrm{mol} \cdot \mathrm{m}^{-2} \cdot \mathrm{s}^{-1}$ ) the optimal temperature was between $20^{\circ} \mathrm{C}$ and $25^{\circ} \mathrm{C}$. These studies show that the photosynthetic capacity of Sphagnum plants has a rather high optimal temperature range at $20^{\circ} \mathrm{C}$ to $25^{\circ} \mathrm{C}$, even though Sphagnum plants successfully distribute in the circumpolar region.

In this paper we investigated the temperature dependence of the carbon assimilation rate of five Sphagnum species growing in warm-temperate and cool-temperate zones in Japan. We measured the response of the $\mathrm{CO}_{2}$ exchange rate of the Sphagnum species along a temperature range of $5^{\circ} \mathrm{C}-40^{\circ} \mathrm{C}$, a much wider range compared to those previously reported. Furthermore, we tried to test the hypothesis that Sphagnum species can tolerate higher temperature conditions than those in their native distribution areas. We also tried to clarify the differences in temperature dependence for the photosynthetic rates found among various species and climatic zones. Measuring optimum temperatures for photosynthetic rates and making interspecific comparisons provided information on the adaptation of Sphagnum plants to low temperature environments. Additionally, we discussed the adaptive traits of Sphagnum species and the responses of community structure to global climatic change.

\section{Materials and Methods}

\subsection{Plant Materials}

Sphagnum samples were collected from the Tadewara mire in south-western Japan $\left(33.07^{\circ} \mathrm{N}, 131.14^{\circ} \mathrm{E}, 1000 \mathrm{~m}\right.$ a.s.l.) in June 2007, and the East Ochiishi mire in northeastern Japan $\left(43.16^{\circ} \mathrm{N}, 145.50^{\circ} \mathrm{E}, 50 \mathrm{~m}\right.$ a.s.l.) in September 2007.

The Tadewara mire (measuring $1.0 \mathrm{~km}$ east to west, and $3.0 \mathrm{~km}$ north to south) is located within the Kujyu volcanic mountain area at $1000 \mathrm{~m}$ a.s.l. The mire developed on the gentle slope at the end an alluvial fan. Annual mean temperature in the mire was $9.1^{\circ} \mathrm{C}$, average daily maximum temperature was $25.6^{\circ} \mathrm{C}$ in August, av- 
erage daily minimum temperature was $-6.2^{\circ} \mathrm{C}$ in January, annual precipitation was $2720 \mathrm{~mm}$, and maximum snow accumulation was $12 \mathrm{~cm}$ in January (data from the Japan Meteorological Agency between 1971 and 2000). Annual precipitation in the Kujyu mountain area is reported to be up to $3500 \mathrm{~mm}$ [28]. The upper part (southern area) of the Tadewara mire is covered with a grassland dominated by Miscanthus sinensis Anderss. and the lower part (northern area) of the mire is covered by mesotrophic to ombrotrophic mire vegetation dominated by Phragmites australis (Cav.) Trin. ex Steud., Moliniopsis japonica (Hack.) Hayata, and Hydrangea paniculata Sieb. et Zucc. Two Sphagnum species, Sphagnum palustre L. (section Palustria or Sphagnum) and Sphagnum fimbriatum Wils. ex Wils. \& Hookf. (section Acutifolia) distribute in the central area of the mire community. The depth of the peat layer at the center of the Sphagnum dominated mire was $4.2 \mathrm{~m}$ and the layer lower than $163 \mathrm{~cm}$ contains large amounts of volcanic mineral deposition (C contents $<5 \% \mathrm{w} / \mathrm{w}$; Haraguchi et al., unpublished data).

Another sampling site, the East Ochiishi mire was in the Ochiishi district, Nemuro, in north-eastern Japan. Some ombrogenous mires were established on the coastal terrace at 40 - $50 \mathrm{~m}$ a.s.l, having been formed by the Nemuro Group in the Upper Cretaceous. The annual mean temperature in the East Ochiishi mire was $5.7^{\circ} \mathrm{C}$, average daily maximum temperature was $20.5^{\circ} \mathrm{C}$ in $\mathrm{Au}-$ gust, average daily minimum temperature was $-9.3^{\circ} \mathrm{C}$ in February, annual precipitation was $1031 \mathrm{~mm}$, and maximum snow accumulation was $23 \mathrm{~cm}$ in February (data from the Japan Meteorological Agency between 1971 and 2000). A Picea glehnii (Fr. Schm.) Masters. forest was estab- lished on the mire in conjunction with the Sphagnum- dominated mire [29]. The site description and description of the vegetation structure of the mires in the Ochiishi district appear in [29]. Sphagnum plants were collected from the East Ochiishi mire, which has a peat accumula- tion of $1.3-1.5 \mathrm{~m}$. Several tephra layers are included in the peat layer, and the latest layer of the Holocene tephra originating from Tarumae Volcano (Ta-a; 1739 AD) ap- pears at a depth of $10-15 \mathrm{~cm}$. The dominant Sphagnum species in the mire are Sphagnum fuscum (Schimp.) Klinggr. (section Acutifolia) and $S$. papillosum Lindb. (section Palustria). Sphagnum fallax Klinggr. (section Cuspidata), S. girgensohnii Russ. (section Acutifolia) and $S$. squarrosum Crome (section Squarrosa) were abundant on the $P$. glehnii forest floor. We collected $S$. papillosum, $S$. fuscum and $S$. fallax from the East Ochiishi mire.

Sphagnum samples of $10 \mathrm{~cm}$ length with capitula were excised in the field and stored in air-tight plastic bags immediately after sample collection. Samples were trans- ferred to the laboratory at room temperature and samples were cultivated at $\mathrm{T}=25^{\circ} \mathrm{C}$ under 12L12D illuminated with PPFD is $40 \mu \mathrm{mol} \cdot \mathrm{m}^{-2} \cdot \mathrm{s}^{-1}$ until photosynthesis measurements were made. Plants were submerged in pure water except for the capitula and water was supplied at 1 2 day intervals, thus preventing plants from entering the atmosphere. Photosynthesis measurements were made within 10 days from the beginning of cultivation and the plant samples were kept in good physiological condition for the measurement.

\subsection{Measurements of Photosynthesis and Dark Respiration Rates}

Capitula segments of $1 \mathrm{~cm}$ from the apex were excised from the shoots of Sphagnum plants and regularly arranged on Petri dishes. Twelve capitula were used for measurements for $S$. palustre, S. fimbriatum, S. papillosum and $S$. fallax, whereas 15 capitula were used for $S$. fuscum. Plant materials were submerged in water and preliminary illumination was provided in the growth chamber at $\mathrm{T}=20^{\circ} \mathrm{C}$ for more than 24 hours at PPFD = $90 \mu \mathrm{mol} \cdot \mathrm{m}^{-2} \cdot \mathrm{s}^{-1}$. Water in the Petri dish was removed just before the photosynthesis measurements.

Photosynthetic rates and dark respiration rates for the Sphagnum spp. were measured by $\mathrm{CO}_{2}$ exchange rate in a chamber with a constant flow of air. Ambient air $\left(\mathrm{CO}_{2}\right.$ concentration 420 - $470 \mathrm{ppm}$ ) was pooled in a gas bag $\left(3.5 \mathrm{~m}^{3}\right)$ and supplied the air at $1.0 \mathrm{~L} \cdot \mathrm{min}^{-1}$ to the chamber after saturation of humidity by flushing through water. Concentration of $\mathrm{CO}_{2}$ before and after the chamber was measured by infrared $\mathrm{CO}_{2}$ analyzer (LI-COR, LI840). The chamber $(13 \mathrm{~cm} \times 10 \mathrm{~cm} \times 4.5 \mathrm{~cm})$ was made of polypropylene and the upper surface of the chamber was made of acryl transparency plate $(10.2 \mathrm{~cm} \times 7 \mathrm{~cm})$. The chamber was placed in a $100 \mathrm{~L}$ water bath and water temperature was controlled by a temperature control system (TAITEC, CL-150R). Irradiation was provided by four $500 \mathrm{~W}$ halogen lamps and the photon flux density of photosynthetically active radiation (PPFD) was measured by a PPFD sensor in water (LI-COR, LI- 250A).

Petri dishes with Sphagnum capitula were placed in the plastic chamber. The chamber was submerged in water and water temperature was controlled by circulating water. Measurement of $\mathrm{CO}_{2}$ concentration started $30 \mathrm{~min}$ after setting up the chamber. Readings of the $\mathrm{CO}_{2}$ concentration became stable within $30 \mathrm{~min}$. Concentrations of $\mathrm{CO}_{2}$ were recorded at $1 \mathrm{sec}$ intervals. $\mathrm{CO}_{2}$ concentrations flowing both in and out of the chamber were alternately measured at $10 \mathrm{sec}$ intervals. PPFD at the surface of plant samples and water temperature just at the surface of the chamber were recorded for each measurement.

PPFD changed from ca. $800 \mu \mathrm{mol} \cdot \mathrm{m}^{-2} \cdot \mathrm{s}^{-1}$ to 0 
$\mu \mathrm{mol} \cdot \mathrm{m}^{-2} \cdot \mathrm{s}^{-1}$ and $\mathrm{CO}_{2}$ concentrations were measured at 15 different PPFD levels. Dark respiration was measured by covering the chamber with a dark net. Temperature was changed from $5^{\circ} \mathrm{C}$ to $40^{\circ} \mathrm{C}$ at $5^{\circ} \mathrm{C}$ intervals. A chamber without plant samples was used as a reference and the $\mathrm{CO}_{2}$ concentration of the reference chamber was used as a blank.

After measurement of the $\mathrm{CO}_{2}$ exchange rate, plant samples were dried at $\mathrm{T}=70^{\circ} \mathrm{C}$ for 24 hours and dry weights of the plants were measured. Photosynthetic and respiration rates were calculated on a dry-weight basis.

\section{Results}

Absolute photosynthetic rates of Sphagnum spp. showed high variance between individual plants, and we presented PPFD-photosynthetic rate response curves by the relative rate (\%) per maximum rate within the measurements using the same plant samples (Figure 1). Absolute values for photosynthetic rate appear in Figure 2. PPFDgross photosynthetic rate response curves showed significant temperature dependence for every species. S. fimbriatum from the Tadewara mire showed the maximum photosynthetic rate at $\mathrm{T}=25^{\circ} \mathrm{C}$, and the rate maintained higher values within the temperature range of $\mathrm{T}=15^{\circ} \mathrm{C}$ $35^{\circ} \mathrm{C}$ (Figure 1(a)). Within the temperature range of $15^{\circ} \mathrm{C}$ to $35^{\circ} \mathrm{C}$, the maximum photosynthetic rate was obtained at PPFD $=320-450 \mu \mathrm{mol} \cdot \mathrm{m}^{-2} \cdot \mathrm{s}^{-1}$ and the rate decreased at PPFD $>450 \mu \mathrm{mol} \cdot \mathrm{m}^{-2} \cdot \mathrm{s}^{-1}$. The gross photosynthetic rate of $S$. fimbriatum showed lower values at $\mathrm{T}=5^{\circ} \mathrm{C}, 10^{\circ} \mathrm{C}$ and $40^{\circ} \mathrm{C}$, and the maximum photosynthetic rates were obtained at PPFD $=200-250 \mu \mathrm{mol} \cdot \mathrm{m}^{-2} \cdot \mathrm{s}^{-1}$ at T $=5^{\circ} \mathrm{C}$ and $10^{\circ} \mathrm{C}$.

$S$. palustre from the Tadewara mire showed maximum photosynthetic rates at $\mathrm{T}=25^{\circ} \mathrm{C}-30^{\circ} \mathrm{C}$ and the rates remained almost the same within the temperature range (Figure 1(b)). At $\mathrm{T}=35^{\circ} \mathrm{C}$, photosynthetic rates for $S$. palustre significantly decreased at PPFD $>490 \mu \mathrm{mol} \cdot \mathrm{m}^{-2} \cdot \mathrm{s}^{-1}$, whereas the decrease in photosynthetic rates at PPFD > $660 \mu \mathrm{mol} \cdot \mathrm{m}^{-2} \cdot \mathrm{s}^{-1}$ was not significant at $\mathrm{T}=25^{\circ} \mathrm{C}$ and $30^{\circ} \mathrm{C}$. Photosynthetic rates for $S$. palustre at $\mathrm{T}=5^{\circ} \mathrm{C}$ were the lowest, and the rate decreased at PPFD $>120$ $\mu \mathrm{mol} \cdot \mathrm{m}^{-2} \cdot \mathrm{s}^{-1}$. The gross photosynthetic rate decreased at PPFD $>80 \mu \mathrm{mol} \cdot \mathrm{m}^{-2} \cdot \mathrm{s}^{-1}$ at $\mathrm{T}=40^{\circ} \mathrm{C}$.

$S$. fuscum from the East Ochiishi mire showed maximum gross photosynthetic rate at $\mathrm{T}=35^{\circ} \mathrm{C}$ and the higher rate was maintained within the temperature range of $\mathrm{T}=$ $30^{\circ} \mathrm{C}-40^{\circ} \mathrm{C}$ (Figure 1(c)). At $\mathrm{T}=30^{\circ} \mathrm{C}$, the gross photosynthetic rate of $S$. fuscum slightly decreased at PPFD > $550 \mu \mathrm{mol} \cdot \mathrm{m}^{-2} \cdot \mathrm{s}^{-1}$, whereas no decrease in photosynthetic rate at high light intensity was observed at $\mathrm{T}=35^{\circ} \mathrm{C}$ and $40^{\circ} \mathrm{C}$. The photosynthetic rate for $S$. fuscum at $\mathrm{T}=5^{\circ} \mathrm{C}$ was the lowest.
S. papillosum from the East Ochiishi mire showed a maximum photosynthetic rate at $\mathrm{T}=35^{\circ} \mathrm{C}$, and the rate maintained higher values within the temperature range of $\mathrm{T}=30^{\circ} \mathrm{C}-35^{\circ} \mathrm{C}$ (Figure 1(d)). Even at $\mathrm{T}=40^{\circ} \mathrm{C}$, the photosynthetic rate of $S$. papillosum remained almost the same as that measured at $\mathrm{T}=25^{\circ} \mathrm{C}$. The photosynthetic rate of $S$. papillosum showed its lowest value at $\mathrm{T}=5^{\circ} \mathrm{C}$, and the rate decreased at PPFD $>530 \mu \mathrm{mol} \cdot \mathrm{m}^{-2} \cdot \mathrm{s}^{-1}$.

$S$. fallax from the East Ochiishi mire showed a maximum photosynthetic rate at $\mathrm{T}=30^{\circ} \mathrm{C}$, and the rate maintained higher values within a temperature range of $\mathrm{T}=$ $25^{\circ} \mathrm{C}-40^{\circ} \mathrm{C}$ (Figure 1(e)). The photosynthetic rate of $S$. fallax showed its lowest value at $\mathrm{T}=5^{\circ} \mathrm{C}$, and the rate decreased at PPFD $>270 \mu \mathrm{mol} \cdot \mathrm{m}^{-2} \cdot \mathrm{s}^{-1}$.

Light intensity at the saturated photosynthetic rate was $200-300 \mu \mathrm{mol} \cdot \mathrm{m}^{-2} \cdot \mathrm{s}^{-1}$ (Figure 1) and the value was quite similar to the reported values [30-32]. Many of the response curves showed a decrease in photosynthetic rate when PPFD exceeded $300 \mu \mathrm{mol} \cdot \mathrm{m}^{-2} \cdot \mathrm{s}^{-1}$. Thus, neither the hyperbolic response curve nor the non-rectangular hyperbola model [33] was applicable for the regression of the PPFD-photosynthesis response curve obtained here. At first we applied the non-rectangular hyperbola model excluding the experimental data for higher PPFDs than that at which the maximum photosynthetic rate was obtained. The non-rectangular hyperbola model is represented by the formula:

$$
\begin{aligned}
& \theta \mathrm{P}_{\mathrm{s}}^{2}-\left(\mathrm{P}_{\max }+\alpha \mathrm{I}-\theta \mathrm{R}_{\mathrm{d}}\right) \mathrm{P}_{\mathrm{s}} \\
& +\alpha \mathrm{I}\left(\mathrm{P}_{\max }-(1-\theta) \mathrm{R}_{\mathrm{d}}\right)-\mathrm{R}_{\mathrm{d}} \mathrm{P}_{\mathrm{s}}=0
\end{aligned}
$$

where $\mathrm{P}_{\mathrm{s}}$ is the net $\mathrm{CO}_{2}$ assimilation rate $\left(\mu \mathrm{mol} \cdot \mathrm{CO}_{2} \cdot \mathrm{m}^{-2} \cdot \mathrm{s}^{-1}\right)$, I is the PPFD ( $\mu$ mol-photon $\left.\cdot \mathrm{m}^{-2} \cdot \mathrm{s}^{-1}\right), \mathrm{R}_{\mathrm{d}}$ is the rate of dark respiration expressed as $\mathrm{CO}_{2}$ production $(\mu \mathrm{mol}-$ $\left.\mathrm{CO}_{2} \cdot \mathrm{m}^{-2} \cdot \mathrm{s}^{-1}\right), \mathrm{P}_{\max }$ is the light-saturated rate of gross $\mathrm{CO}_{2}$ assimilation $\left(\mu \mathrm{mol}-\mathrm{CO}_{2} \cdot \mathrm{m}^{-2} \cdot \mathrm{s}^{-1}\right.$ ), and $\theta$ and $\alpha$ are constants determining curvature at the shoulder and apparent quantum efficiency (initial slope at zero irradiance of the light-photosynthetic rate relationship curve), respectively. $\mathrm{R}_{\mathrm{d}}$ was obtained from the experimental data, and the light response curve of the gross photosynthetic rate was obtained by substituting $R_{d}=0$ in the equation.

Maximum photosynthetic rates $\left(\mathrm{P}_{\max }\right)$ estimated by the non-rectangular hyperbola model (excluding data for higher PPFDs if the PPFD-photosynthesis curves showed a decreasing tendency at higher PPFDs) were obtained at $\mathrm{T}=35^{\circ} \mathrm{C}$ for $S$. palustre, $S$. fuscum and $S$. papillosum, and at $\mathrm{T}=30^{\circ} \mathrm{C}$ for $S$. fimbriatum and S. fallax (Figure 2(a)). Although temperature dependence for $P_{\max }$ was significant ( $<<0.05$ ) only for $S$. palustre by the KruskalWallis test, $\mathrm{P}_{\max }$ at $\mathrm{T}=40^{\circ} \mathrm{C}$ was $70 \%-85 \%$ of $\mathrm{P}_{\max }$ at T $=35^{\circ} \mathrm{C}$ for northern species ( $S$. fuscum, $S$. fallax and $S$. 


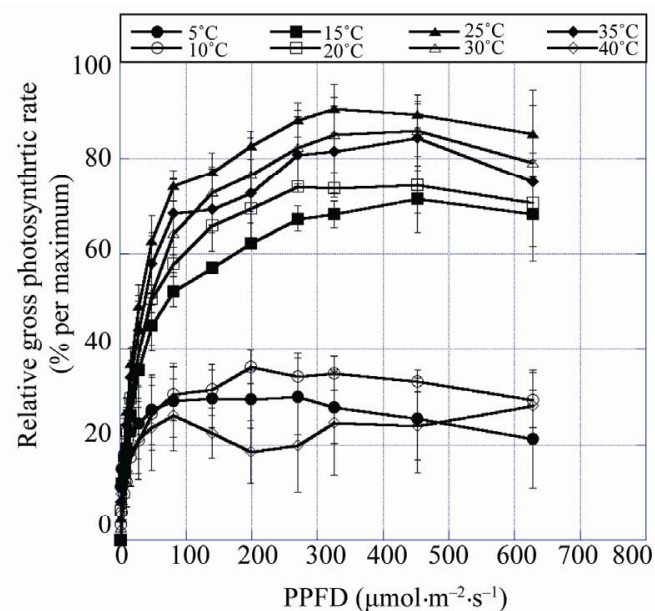

(a)

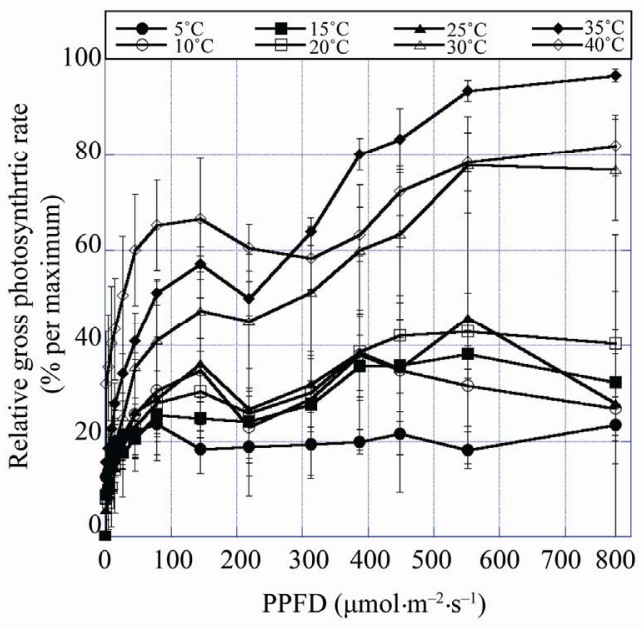

(c)

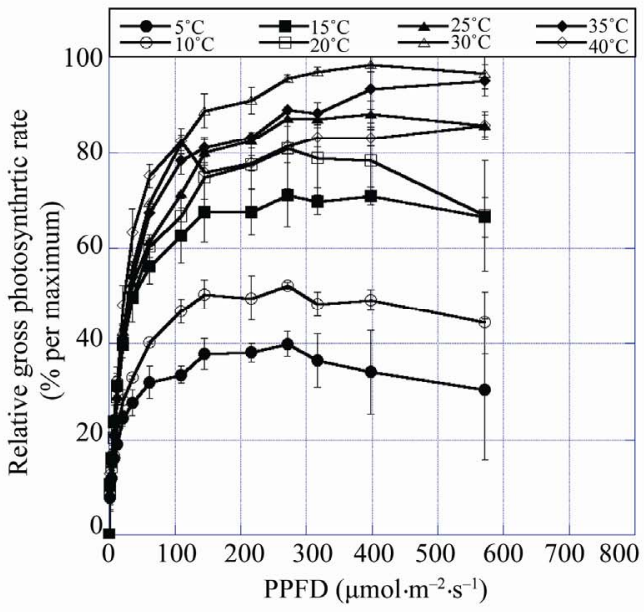

(e)

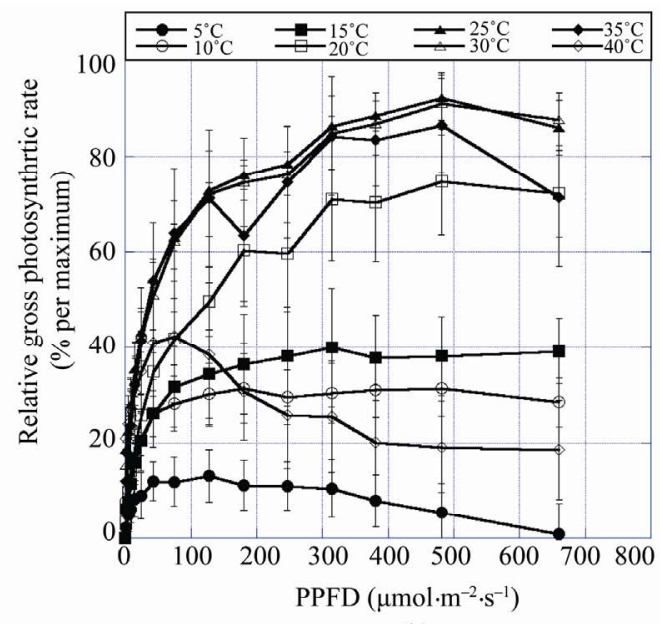

(b)

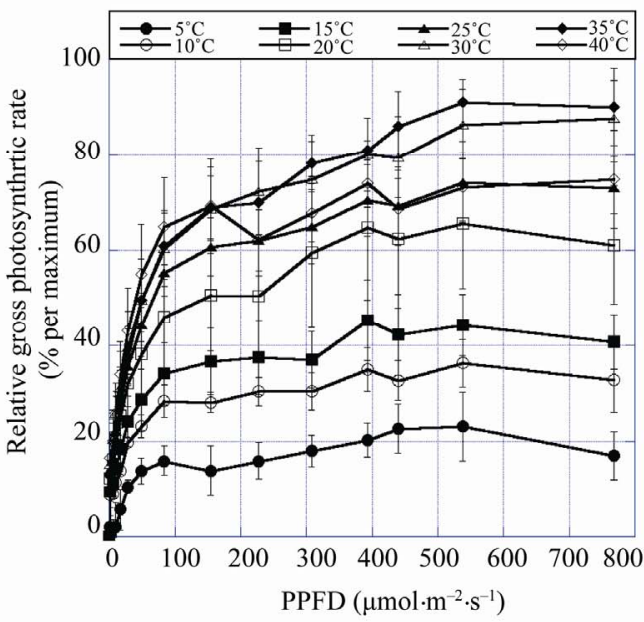

(d)

Figure 1. Relative gross photosynthetic rate (\% per maximum) and PPFD relationship curve of (a) Sphagnum fimbriatum; (b) S. palustre (from the Tadewara mire in northern Kyushu, Japan); (c) S. fuscum; (d) S. papillosum; (e) S. fallax (from the East Ochiishi mire in north-eastern Hokkaido, Japan) at temperatures of $5^{\circ} \mathrm{C}, 10^{\circ} \mathrm{C}, 15^{\circ} \mathrm{C}, 20^{\circ} \mathrm{C}, 25^{\circ} \mathrm{C}, 30^{\circ} \mathrm{C}, 35^{\circ} \mathrm{C}$, and $40^{\circ} \mathrm{C}$. 


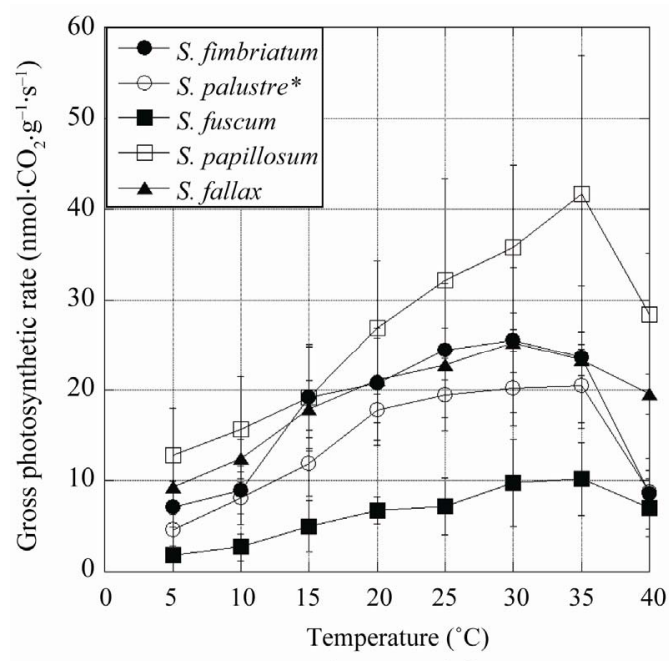

(a)

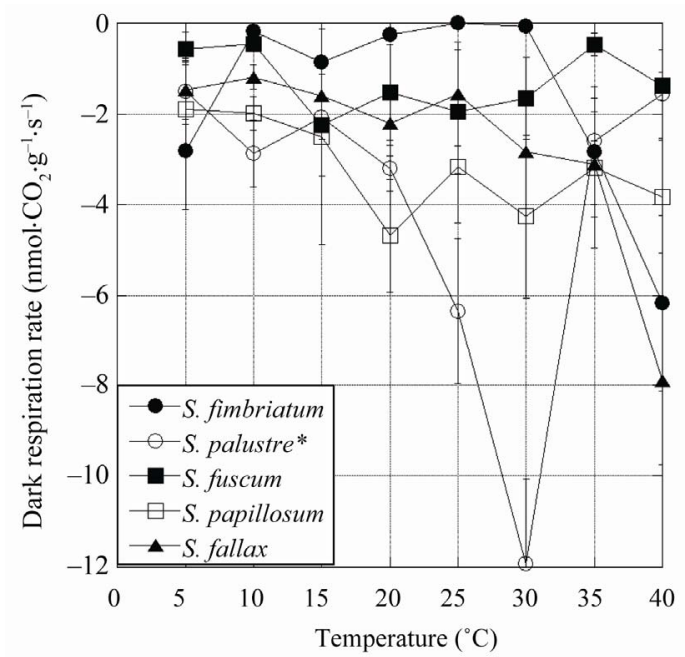

(b)

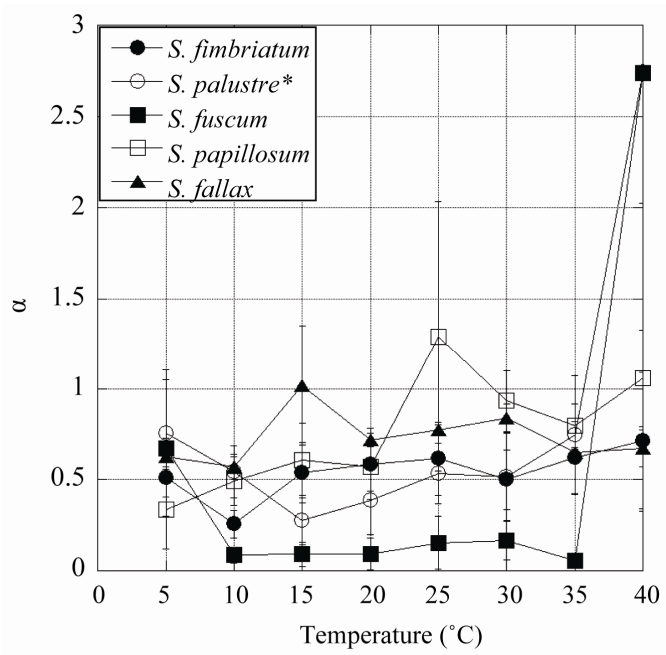

(c)

Figure 2. (a) Temperature dependence of gross photosynthetic rate $\left(\mathbf{P}_{\max }\right)$, (b) dark respiration $\left(\mathbf{R}_{\mathrm{d}}\right)$ and $(\mathrm{c})$ apparent quantum efficiency (slope of PPFD-photosynthesis response curve at 0 irradiation; $(\alpha)$ of Sphagnum fimbriatum $(\bullet), S$. palustre $(O)$, S. fuscum ( $\square)$, S. papillosum $(\square)$, and S. fallax $(\mathbf{\Delta}) . P_{\max }$ and $\alpha$ were estimated using a non-rectangular hyperbola model excluding data for higher irradiation if PPFD-photosynthetic rate curves showed decreasing tendencies at higher irradiation. $\mathbf{R}_{\mathrm{d}}$ was measured directly.

papillosum), whereas the ratio was $30 \%-40 \%$ for southern species (S. fimbriatum and S. palustre). Relative gross $\mathrm{P}_{\max }$ (\% per maximum) determined by using the data for relative photosynthetic rate within the same plant samples presented in Figure 1 showed significant temperature dependence for every species: $S$. fimbriatum (p < 0.01), S. palustre (p < 0.01), S. fuscum (p < 0.01), $S$. papillosum $(\mathrm{p}<0.01)$ and $S$. fallax $(\mathrm{p}<0.05)$ by the Kruskal-Wallis test.

Dark respiration $\left(\mathrm{R}_{\mathrm{d}}\right)$ for $S$. fimbriatum increased over $\mathrm{T}=30^{\circ} \mathrm{C}$ and showed a maximum at $\mathrm{T}=40^{\circ} \mathrm{C}$ (Figure 2(b)). S. fallax showed a tendency similar to that of $S$. fimbriatum and $\mathrm{R}_{\mathrm{d}}$ increased over $\mathrm{T}=30^{\circ} \mathrm{C}$ and showed a maximum at T $=40^{\circ} \mathrm{C}$. $\mathrm{R}_{d}$ for $S$. fuscum and S. papillosum showed a maximum around $\mathrm{T}=15^{\circ} \mathrm{C}-20^{\circ} \mathrm{C}$, although the temperature dependence was not significant. $S$. palustre showed a maximum $\mathrm{R}_{\mathrm{d}}$ at $\mathrm{T}=30^{\circ} \mathrm{C}$, but the extremely high $\mathrm{R}_{\mathrm{d}}$ value for $S$. palustre could be due to some error in measurement. Temperature dependence for $\mathrm{R}_{\mathrm{d}}$ was significant $(\mathrm{p}<0.05)$ only for $S$. palustre.

Apparent quantum efficiency $(\alpha)$ did not show significant temperature dependence ( $\mathrm{p}>0.05$ ) for any of the species (Figure 2(c)). However, S. palustre and S. fuscum showed extremely high values at $\mathrm{T}=40^{\circ} \mathrm{C}$. Slope of 
the PPFD-photosynthetic rate response curve at zero irradiance determined by using the relative photosynthetic rate (\% per maximum) that corresponds to $\alpha$ also showed no significant temperature dependence $(p>0.05)$ for any of the species.

After the estimation of photosynthetic parameters using the non-rectangular hyperbola model, a fourth function equation was applied for the experimental data, including all the data at higher PPFDs. The equation provided the best fit for most of the PPFD-photosynthesis response curves which showed a decline of photosynthetic rate at higher PPFDs. Then we used the fourth function equation to obtain an estimated value. However, this equation does not have any physiological meaning for describing the regression of photosynthetic rates in relation to PPFDs.

Photosynthetic rates for the five Sphagnum species distributed in the Tadewara mire and the East Ochiishi mire showed obvious temperature dependence (Figure 3). Fits for the photosynthesis response curves in relation to PPFD were found using the fourth function equation and were used to estimate the rates at low light intensity $\left(\right.$ PPFD $\left.=150 \mu \mathrm{mol} \cdot \mathrm{m}^{-2} \cdot \mathrm{s}^{-1}\right)$ and high light intensity $\left(\mathrm{PPFD}=500 \mu \mathrm{mol} \cdot \mathrm{m}^{-2} \cdot \mathrm{s}^{-1}\right)$. S. fimbriatum, S. palustre and $S$. fuscum showed significant differences in photosynthetic rates among various temperature conditions by the Kruskal-Wallis test, both at the low and high light intensities $(\mathrm{p}<0.05$ for $S$. palustre at PPFD $=150$ $\mu \mathrm{mol} \cdot \mathrm{m}^{-2} \cdot \mathrm{s}^{-1}, \mathrm{p}<0.001$ for $S$. fuscum at PPFD $=500$ $\mu \mathrm{mol} \cdot \mathrm{m}^{-2} \cdot \mathrm{s}^{-1}, \mathrm{p}<0.01$ for others). S. fallax showed significant differences in photosynthetic rates among various temperature conditions at PPFD $=500 \mu \mathrm{mol} \cdot \mathrm{m}^{-2} \cdot \mathrm{s}^{-1}(\mathrm{p}<$

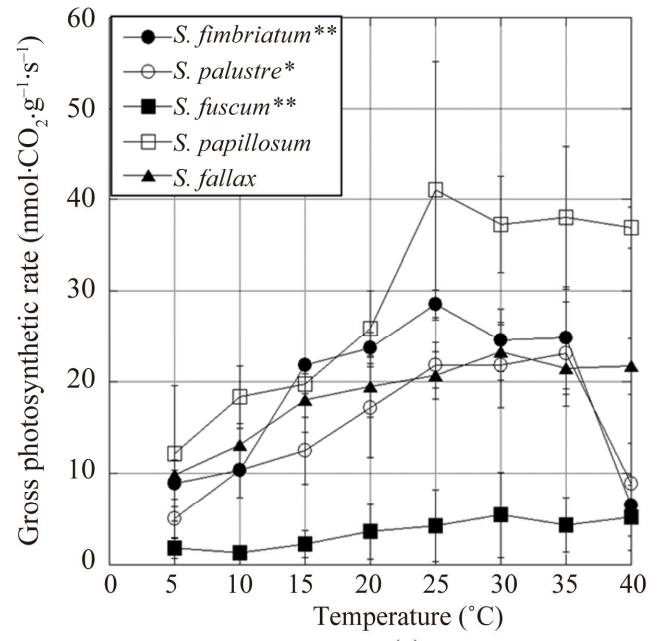

(a)
0.05; Figure 4). S. papillosum did not show significant dependence between its photosynthetic rate and the varying temperature conditions $(\mathrm{p}>0.05)$.

Although temperature dependence at optimal PPFDs that showed maximum rates for gross photosynthesis at each temperature was significant only for S. palustre $(\mathrm{p}<$ $0.05)$, PPFD at $\mathrm{P}_{\max }$ tended to increase with increasing temperature. $S$. palustre showed the lowest value at $\mathrm{T}=$ $40^{\circ} \mathrm{C}$.

\section{Discussion}

The temperature dependence of photosynthetic rate was observed for every species of Sphagnum studied here. Apparent quantum efficiency $(\alpha)$ did not show significant temperature dependence (Figure 2(c)), and hence biochemical reaction is the rate-determining reaction depending on temperature. Temperature dependence levels in relation to the photosynthetic rate were quite similar for all the species at a temperature of $\mathrm{T}<25^{\circ} \mathrm{C}$, and the $\mathrm{Q}_{10}$ value from $\mathrm{T}=10^{\circ} \mathrm{C}$ to $20^{\circ} \mathrm{C}$ was $1.70-2.47$ (Figure 2(a)).

Temperature dependence of the photosynthetic rates at high temperature $\left(\mathrm{T}>25^{\circ} \mathrm{C}\right)$ showed differences among the species. $S$. fimbriatum and $S$. palustre from the Tadewara mire showed significant decreases of photosynthetic rate at $\mathrm{T}=40^{\circ} \mathrm{C}$ compared to the results for $\mathrm{T}=$ $35^{\circ} \mathrm{C}$ and the rates of $S$. fimbriatum and $S$. palustre at $\mathrm{T}=$ $40^{\circ} \mathrm{C}$ were $36 \%$ and $43 \%$ of those at $\mathrm{T}=35^{\circ} \mathrm{C}$, respectively, whereas the rates at $\mathrm{T}=40^{\circ} \mathrm{C}$ for $S$. fuscum, $S$. papillosum and $S$. fallax from the East Ochiishi mire were slightly lower than the rates at $\mathrm{T}=35^{\circ} \mathrm{C}$. The rates for $S$. fuscum, $S$. papillosum, and $S$. fallax at $\mathrm{T}=40^{\circ} \mathrm{C}$

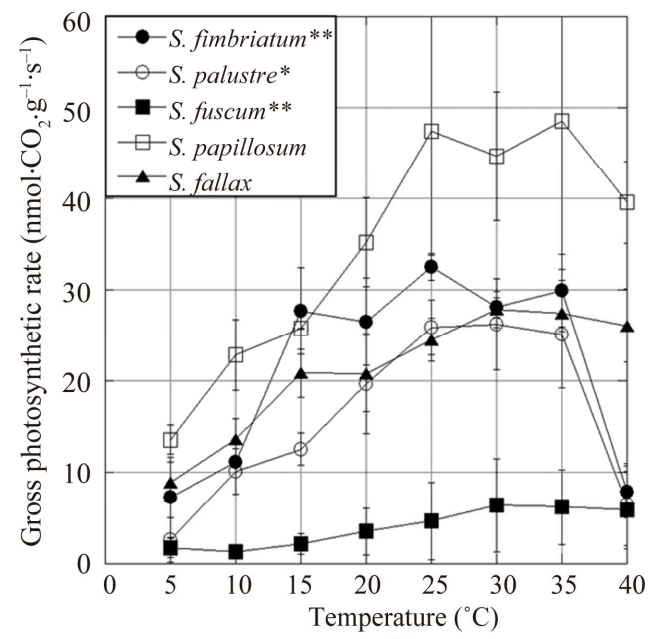

(b)

Figure 3. Temperature dependence of gross photosynthetic rate $\left(P_{\max }\right)$ of Sphagnum fimbriatum (O), S. palustre (O), S. fuscum ( $\square$ ), S. papillosum ( $\square$ ), and $S$. fallax (A) at (a) PPFD $=150 \mu \mathrm{mol} \cdot \mathrm{m}^{-2} \cdot \mathrm{s}^{-1}$ and (b) PPFD $=500 \mu \mathrm{mol} \cdot \mathrm{m}^{-2} \cdot \mathrm{s}^{-1} \mathrm{estimated}$ based on regression using a fourth function equation. 


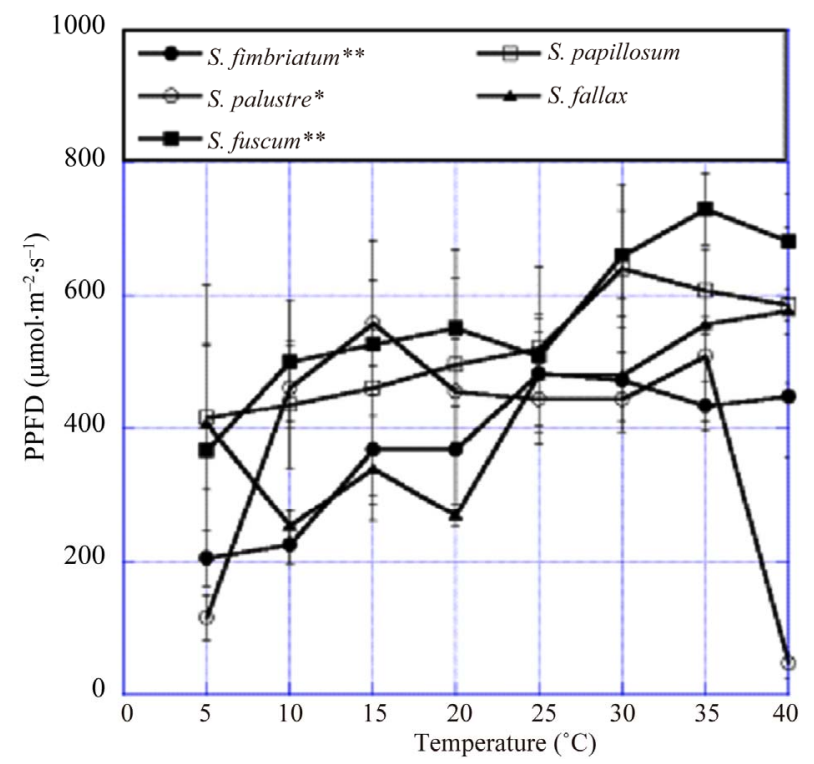

Figure 4. Optimal PPFDs showing maximum rates of photosynthesis in PPFD-gross photosynthesis response curves measured at each temperature. Species are Sphagnum fimbriatum (O), S. palustre (O), S. fuscum (ם), S. papillosum $(\square)$, and $S$. fallax (A).

were $69 \%, 68 \%$ and $84 \%$ of those obtained at $\mathrm{T}=35^{\circ} \mathrm{C}$, respectively.

Thus we found that the photosynthetic rates of the two species from the Tadewara mire decreased when temperature exceeded $35^{\circ} \mathrm{C}$, whereas the rates of the three species from the East Ochiishi mire did not decrease when the temperature was $40^{\circ} \mathrm{C}$.

Especially under low temperature conditions, the photosynthetic rates for Sphagnum spp. under conditions of high PPFD were lower than rates obtained under low PPFD conditions. This shows that photosynthesis was inhibited by high PPFD in low temperature environments. Inhibition of photosynthesis by high PPFD levels has been reported for some species, e.g., tomato, Nicotiana tabacum, and Camellia sinensis at $\mathrm{T}=0^{\circ} \mathrm{C}-15^{\circ} \mathrm{C}$ [34-37]. Most of these reports are for vascular plants sensitive to low temperature stress. Our observations showed that inhibition of photosynthesis by high PPFDs under low temperature conditions was evident for Sphagnum spp. whose distribution was mostly in the circumpolar region.

Apparent quantum efficiencies $(\alpha)$ were not significantly different among the various temperature conditions created for each of the species. This implies that photoreaction in Sphagnum plants is not significantly affected by temperature.

Dark respiration $\left(\mathrm{R}_{\mathrm{d}}\right)$ commonly shows a tendency to increase with increasing temperature, and the net photosynthetic rate and the consequent net primary production showed maximum levels at temperatures lower than the optimum temperature for gross photosynthetic rate. However, $\mathrm{R}_{\mathrm{d}}$ in our measurements of Sphagnum spp. did not significantly increase up to $\mathrm{T}=40^{\circ} \mathrm{C}$. Respiration in Sphagnum plants showed an adaptive trend as photosynthetic capacity at higher temperatures.

Although Sphagnum species dominate in mires in low temperature regions and these species are the successful plants in low temperature environments, the physiological properties of Sphagnum may not have fully adapted to low temperature conditions. Considering the fact that Sphagnum spp. distribute also in tropical lowland areas with high temperatures [38], Sphagnum species may have potential for distribution in tropical regions.

\section{Acknowledgements}

Authors thank to the member of the University of Kitakyushu for their assistance in field study. This study was partly funded by the Seven-Eleven Midorinokikin Fund, JSPS Grant-in-Aid for Scientific Research 18208019 \& 20248033, and the River Fund in Charge of the Foundation of River and Watershed Environment Management, Japan.

\section{REFERENCES}

[1] M. Mäkilä, M. Saarnisto and T. Kankainen, “Aapa Mires as a Carbon Sink and Source during the Holocene,” Journal of Ecology, Vol. 89, No. 4, 2001, pp. 589-599. doi:10.1046/j.0022-0477.2001.00586.X

[2] S. K. Kivimäki, M. Yli-petäys and E. Tuittila, "Carbon Sink Function of Sedge and Sphagnum Patches in a Restored Cut-Away Peatland: Increased Functional Diversity Leads to Higher Production," Journal of Applied Ecology, Vol. 45, 2008, pp. 921-929.

[3] R. S. Clymo and P. M. Hayward, “The Ecology of Sphagnum,” In: A. J. E. Smith, Ed., Bryophyte Ecology, Chapman and Hall, London, 1982, pp. 229-289. doi:10.1007/978-94-009-5891-3_8

[4] P. M. Hayward and R. S. Clymo, "The Growth of Sphagnum: Experiments on, and Simulation of, Some Effects of Light Flux and Water-Table Depth,” Journal of Ecology, Vol. 71, 1983, pp. 845-863. doi:10.2307/2259597

[5] K. E. Giller and B. D. Wheeler, "Acidification and Succession in a Flood-Plain Mire in the Norfolk Broadland, U.K.,” Journal of Ecology, Vol. 76, 1988, pp. 849-866. doi:10.2307/2260577

[6] K. J. Murray, P. C. Harley, J. Beyers, H. Walz and J. D. Tenhunen, "Water Content Effects on Photosynthetic Response of Sphagnum Mosses from the Foothills of the Philip Smith Mountains, Alaska,” Oecologia, Vol. 79, No. 2, 1989, pp. 244-250. doi:10.1007/BF00388484

[7] K. S. Maseyk, T. G. A. Green and D. Klinac, "Photosynthetic Responses of New Zealand Sphagnum Species,” 
New Zealand Journal of Botany, Vol. 37, No. 1, 1999, pp. 155-165. doi:10.1080/0028825X.1999.9512621

[8] K. E. van Gaalen, L. B. Flanagan and D. R.Peddle, "Photosynthesis, Chlorophyll Fluorescence and Spectral Reflectance in Sphagnum Moss at Varying Water Contents," Oecologia, Vol. 153, No. 1, 2007, pp. 19-28. doi:10.1007/s00442-007-0718-y

[9] R. Gerdol, A. Bonora, R. Gualandri and S. Pancaldi, " $\mathrm{CO}_{2}$ Exchange, Photosynthetic Pigment Composition, and Cell Ultrastructure of Sphagnum Mosses during Dehydration and Subsequent Rehydration," Canadian Journal of Botany, Vol. 74, No. 5, 1996, pp. 726-734. doi:10.1139/b96-091

[10] B. Schipperges and H. Rydin, "Response of Photosynthesis of Sphagnum Species from Contrasting Microhabitats to Tissue Water Content and Repeated Desiccation," New Phytologist, Vol. 140, No. 4, 1998, pp. 677-684. doi:10.1046/j.1469-8137.1998.00311.x

[11] R. Aerts, B. Wallén and N. Malmer, "Growth-Limiting Nutrients in Sphagnum-Dominated Bogs Subject to Low and High Atmospheric Nitrogen Supply," Journal of Ecology, Vol. 80, 1992, pp. 131-140. doi: $10.2307 / 2261070$

[12] U. Gunnarsson and H. Rydin, "Nitrogen Fertilization Reduces Sphagnum Production in Bog Communities," New Phytologist, Vol. 147, No. 3, 2000, pp. 527-537. doi:10.1046/j.1469-8137.2000.00717.x

[13] M. M. P. D. Heijmans, H. Klees, W. de Visser and F. Berendse, "Response of a Sphagnum Bog Plant Community to Elevated $\mathrm{CO}_{2}$ and N Supply,” Plant Ecology, Vol. 162, No. 1, 2002, pp. 123-134. doi:10.1023/A:1020368130679

[14] U. Gunnarsson, G. Granberg and M. Nilsson, "Growth, Production and Interspecific Competition in Sphagnum: Effects of Temperature, Nitrogen and Sulphur Treatments on a Boreal Mire," New Phytologist, Vol. 163, No. 2, 2004, pp. 349-359. doi:10.1111/j.1469-8137.2004.01108.x

[15] J. Limpens, F. Berendse and H. Klees, "How Phosphorus Availability Affects the Impact of Nitrogen Deposition on Sphagnum and Vascular Plants in Bogs," Ecosystems, Vol. 7, No. 8, 2004, pp. 793-804. doi:10.1007/s10021-004-0274-9

[16] G. Granath, J. Strengbom, A. Breeuwer, M. M. P. D. Heijmans, F. Berendse and H. Rydin, "Photosynthetic Performance in Sphagnum Transplanted along a Latitudinal Nitrogen Deposition Gradient," Oecologia, Vol. 159, No. 4, 2009, pp. 705-715. doi:10.1007/s00442-008-1261-1

[17] P. Ferguson and J. A. Lee, “The Effects of Bisulphite and Sulphate upon Photosynthesis in Sphagnum," New Phytologist, Vol. 82, No. 3, 1979, pp. 703-712. doi:10.1111/j.1469-8137.1979.tb01665.X

[18] P. Ferguson and J. A. Lee, "Some Effects of Bisulphite and Sulphate on the Growth of Sphagnum Species in the Field,” Environmental Polluttion (Series A), Vol. 21, No.
1, 1980, pp. 59-71. doi:10.1016/0143-1471(80)90033-1

[19] R. Baxter, M. J. Emes and J. A. Lee, "Effects of the Bisulphite Ion on Growth and Photosynthesis in Sphagnum cuspidatum Hoffm,” New Phytologist, Vol. 111, No. 3, 1989, pp. 457-462.

doi:10.1111/j.1469-8137.1989.tb00708.x

[20] R. Baxter, M. J. Emes and J. A. Lee, "Short Term Effects of Bisulphite on Pollution-Tolerant and Pollution Sensitive Populations of Sphagnum cuspidatum Ehrh. (ex Hoffm.)," New Phytologist, Vol. 118, No. 3, 1991, pp. 425-431. doi:10.1111/j.1469-8137.1991.tb00024.x

[21] L. Potter, J. P. Foot, S. J. M. Caporn and J. A. Lee, “The Effects of Long-Term Elevated Ozone Concentrations on the Growth and Photosynthesis of Sphagnum recurvum and Polytrichum commune," New Phytologist, Vol. 134, No. 4, 1996, pp. 649-656. doi:10.1111/j.1469-8137.1996.tb04930.x

[22] R. Niemi, P. J. Martikainen, J. Silvola and T. Holopainen, "Ozone Effects on Sphagnum Mosses, Carbon Dioxide Exchange and Methane Emission in Boreal Peatland Microcosm," Science of the Total Environment, Vol. 289, No. 1-3, 2002, pp. 1-12. doi:10.1016/S0048-9697(01)01012-9

[23] C. Gehrke, "Effects of Enhanced UV-B Radiation on Production-Related Properties of a Sphagnum fuscum Dominated Subarctic Bog,” Functional Ecology, Vol. 12, No. 6, 1998, pp. 940-947. doi:10.1046/j.1365-2435.1998.00273.x

[24] P. S. Searles, S. D. Flint, S. B. Díaz, M. C. Rousseaux, C. L. Ballaré and M. M. Caldwell, "Plant Response to Solar Ultraviolet-B Radiation in a Southern South American Sphagnum Peatland,” Journal of Ecology, Vol. 90, No. 4, 2002, pp. 704-713. doi:10.1046/j.1365-2745.2002.00709.x

[25] T. M. Robson, V. A. Pancotto, S. D. Flint, C. L. Ballaré, O. E. Sala, A. L. Scopel and M. M. Caldwell, "Six Years of Solar UV-B Manipulations Affect Growth of Sphagnum and Vascular Plants in a Tirra Del Fuego Peatland," New Phytologist, Vol. 160, No. 2, 2003, pp. 379-389. doi:10.1046/j.1469-8137.2003.00898.x

[26] A. Breeuwer, M. M. P. D. Heijmans, B. J. M. Robroek and F. Berendse, "The Effect of Temperature on Growth and Competition between Sphagnum Species," Oecologia, Vol. 156, No. 1, 2008, pp. 155-167. doi:10.1007/s00442-008-0963-8

[27] T. G. Williams and L. B. Flanagan, "Measuring and Modeling Environmental Influences on Photosynthetic Gas Exchange in Sphagnum and Pleurozium," Plant, Cell and Environment, Vol. 21, No. 6, 1998, pp. 555-564. doi:10.1046/j.1365-3040.1998.00292.x

[28] H. Kawanishi and M. Nishida, "Meteorology and Hydrology in the Kujyu-Tadewara Mire,” In: Scientific Report on the Kujyu-Tadewara Area, Kokonoe Town and Oita Prefecture, 2002, pp. 9-18.

[29] A. Haraguchi, T. Hasegawa, T. Iyobe and H. Nishijima, "The $\mathrm{pH}$ Dependence of Photosynthesis and Elongation 
of Sphagnum squarrosum and $S$. girgensohnii in the Picea glehnii Mire Forest in Cape Ochiishi, North-Eastern Japan," Aquatic Ecology, Vol. 37, No. 1, 2003, pp. 101-104. doi:10.1023/A:1022130622499

[30] Y. Ino, "Photosynthesis of Antarctic Mosses and Lichens," Japanese Journal of Ecology, in Japanese, Vol. 41, 1991, pp. 149-158.

[31] S. C. Maberly and D. H. N.Spence, "Photosynthetic Inorganic Carbon Use by Freshwater Plants," Journal of Ecology, Vol. 71, 1983, pp. 705-724. doi:10.2307/2259587

[32] P. C. Harley, J. D. Tenhunen, K. J. Murray and J. Beyers, "Irradiance and Temperature Effects on Photosynthesis of Tussock Tundra Sphagnum Mosses from the Foothills of the Philip Smith Mountains, Alaska,” Oecologia, Vol. 79, No. 2, 1989, pp. 251-259. doi:10.1007/BF00388485

[33] J. L. Prioul and P. Chartier, "Partitioning of Transfer and Carboxylation Components of Intracellular Resistance to Photosynthetic $\mathrm{CO}_{2}$ Fixation: A Critical Analysis of the Methods Used," Annals of Botany, Vol. 41, 1977, pp. 789-800.

[34] G. Cornic and G. Louason, "The Effects of $\mathrm{O}_{2}$ on Net
Photosynthesis at Low Temperature $\left(5^{\circ} \mathrm{C}\right)$, , Plant, Cell and Environment, Vol. 3, 1980, pp. 149-157. doi:10.1111/j.1365-3040.1980.tb00108.x

[35] S. B. Powels, J. A. Berry and O. Björkman, "Interaction between Light and Chilling Temperature on the Inhibition of Photosynthesis in Chilling Sensitive Plants," Plant, Cell and Environment, Vol. 6, No. 2, 1983, pp. 117-123. doi:10.1111/j.1365-3040.1983.tb01884.X

[36] G. Bongi and S. P. Long, "Light-Dependent Damage to Photosynthesis in Olive Leaves during Chilling and High Temperature Stress,” Plant, Cell and Environment, Vol. 10, 1987, pp. 241-249

[37] L. A. Netto, K. M. Jayaram, P. Haridas and J. T. Puthur, "Characterization of Photosynthetic Events and Associated Changes in Various Clones of Tea (Camellia Sinensis L.) under Low Temperature Conditions," Journal of Plant Biology, Vol. 48, No. 3, 2005, pp. 326-331. doi:10.1007/BF03030530

[38] T. Asada and A. Haraguchi, "A New Locality of Sphagnum cuspidatum subsp. subrecurvum var. flaccidifolium (A. Johnson) A. Eddy in Central Kalimantan, Indonesia," Bryology Research, in Japanese, Vol. 9, 2006, pp. 87-88. 